\title{
The variability in the hydrosedimentological regime supports high phytoplankton diversity in floodplain: A 12-year survey of the Upper Paraná River
}

\author{
Jascieli Carla BORTOLINI, ${ }^{1,2 *}$ Sueli TRAIN, ${ }^{2,3}$ Luzia Cleide RODRIGUES ${ }^{2,3}$ \\ ${ }^{1}$ Universidade Estadual do Oeste do Paraná, Laboratório de Ficologia, Rua Universitária, 2019, Jardim Universitário, 85819-110, \\ Cascavel, Paraná; ${ }^{2}$ Programa de Pós-graduação em Ecologia de Ambientes Continentais, Departamento de Biologia, Centro de \\ Ciências Biológicas, Universidade Estadual de Maringá, Avenida Colombo, 5790, 87020-900, Maringá, PR; ${ }^{3}$ Núcleo de Pesquisas \\ em Limnologia, Ictiologia e Aquicultura, Universidade Estadual de Maringá, Avenida Colombo, 5790, Bloco H-90, Sala 23, 87020- \\ 900, Maringá, PR, Brazil \\ *Corresponding author: jasci_biologa@hotmail.com
}

\begin{abstract}
The alpha, beta, and gamma diversity are important tools for conservation studies, and the distribution of species in space and time is essential to provide insights regarding diversity patterns and processes that modify the ecosystem and the community responses to such changes. Thus, a long-term ecological date was used to evaluate in 12 biotopes the phytoplankton composition and diversity within selected habitats (alpha diversity), between habitats (beta diversity) and across the upper Paraná River floodplain (gamma diversity). We evaluate the environmental variability of the hydrosedimentological cycles (limnophase and potamophase) during 12 years, associated with the water level variability and with the environmental heterogeneity as drivers of the phytoplankton composition and diversity in the upper Paraná River floodplain. Remarkable gamma diversity was recorded especially in limnophase, however, years with intense flood presented high gamma diversity, and years with extreme drought presented low gamma diversity, although without significant differences. The alpha diversity was significantly different on spatial and temporal scales. The beta diversity showed high values, however with low temporal variability and without correlation with the hydrosedimentological regime of the Paraná River. Overall, these results indicate that the variability in the hydrosedimentological regime associated with the periodicity, duration, and amplitude of limnophase and potamophase, and the pattern of mosaic of habitats in this floodplain are essential for sustaining much of the phytoplankton diversity and ecosystem integrity, and that this approach is relevant and proved be useful to understand floodplain systems and associated phytoplankton community.
\end{abstract}

Key words: Biodiversity; long-term data; planktonic algae; spatial and temporal scale.

Received: May 2016. Accepted: May 2017.

\section{INTRODUCTION}

River-floodplain systems are characterized by a complex spatial and temporal hydrodynamic gradient between the main channel and surrounding wetlands, influenced by hydrosedimentological regime, represented by limnophase (low water level) and potamophase (high water level) (Neiff, 1990). Seasonal flooding is typical of these wetlands and may vary over time in intensity as well as in flood pulse duration (Milzow et al., 2009). This variability, together with the gradients of connectivity, promotes different hydrological, geomorphological, biological and biogeochemical successional processes and results in a dynamic mosaic of habitats with high biodiversity (Ward et al., 1999; Amoros and Bornette, 2002). These systems are among the most productive and diverse ecosystems on Earth, however are among the most threatened (Agostinho et al., 2005; Dittrich et al., 2016).

The study of biodiversity is a key tool for understanding how interactions between disturbance regimes and habitat heterogeneity influence niche diversification and resource partitioning and for determining how functional processes integrate with spatio-temporal heterogeneity (Ward and Tockner, 2001). The distribution of species in space and time has provided insights regarding diversity patterns and processes that modify the ecosystem and the community responses to such changes (Magurran et al., 2010). Thus, studies of biodiversity should emphasize multiple scales of distribution and variability (Giller et al., 2004), once that the community diversity regulates ecological processes such as productivity and stability (Tilman and Downing, 1994; Weyhenmeyer et al., 2013), which are important features especially due of the current intense anthropogenic pressure on natural ecosystems.

Thus, the alpha, beta, and gamma diversity are important tools for conservation studies. Alpha diversity represents the number of taxa occurring in a habitat, gamma diversity represents the total number of taxa in the region, and beta diversity represents the change in species composition along spatial or temporal gradients (Legendre et al., 2005). Therefore, diversity may can be decomposed 
into different components and provide information at both local and regional scales (Pinto et al., 2015).

Phytoplankton is composed of organisms with high growth rates, and its ecology can help determine the effect that environmental modifications in floodplain systems have on diversity and ecosystem dynamics and functions. However, a more detailed understanding of the drivers of species richness and composition in phytoplankton communities is required (Özkan et al., 2013). Evaluating the variability of phytoplankton diversity is essential for providing guidelines for conservation programs aimed at reducing biodiversity losses in conservation areas and understanding the relationship between biodiversity and environmental variables at spatial and temporal scales.

The upper Paraná River floodplain harbors high phytoplankton diversity (Train and Rodrigues, 2004). However, climatic events such as El Niño and La Niña, which are caused by the El Niño-Southern Oscillation (ENSO) cycles (McPhaden et al., 2006) and habitat fragmentation resulting from the construction of Porto Primavera dam that prevent longitudinal connectivity, have changed the hydrosedimentological regime of the upper Paraná River and affected the phytoplankton diversity (Borges and Train, 2009; Bovo-Scomparin et al., 2013; Rodrigues et al., 2009, 2015; Bortolini et al., 2014, 2016a) and others communities (Agostinho et al., 2005; Bonecker et al., 2013; Simões et al., 2013).

Thus, this study aimed to evaluate the influence of hydrosedimentological regime, by the water level and environmental heterogeneity, on phytoplankton composition and diversity, encompassing different habitats in three subbasins of the upper Paraná River floodplain in a long time period. We expect that the phytoplankton composition and diversity components presented different patterns as a response to conditions of each phase (limnophase and potamophase) of the hydrosedimentological cycles through time and of the mosaic of habitats in the floodplain.

\section{METHODS}

\section{Study area}

The Paraná River is the third largest river in South America, and it originates from the union of the Grande and Paranaíba Rivers in the south-central region of Brazil. In its upper third, referred to as the upper Paraná River, is a $230-\mathrm{km}$-long and $20-\mathrm{km}$-wide floodplain. This floodplain encompasses flooded areas on its right bank, including rivers, channels, lakes and backwaters. Backwaters ("ressacos") are lentic water bodies connected to river originating from recently abandoned channels formed by sidebars (Souza Filho and Stevaux, 2004). Thus, floodplains can often be formed by set of habitats associated with a main river channel of a hydrological basin which may be referred to as subsystems (Thomaz et al., 2004; Padial et al., 2012) or even as sub-basin as we follow in this study.

Sampling stations were established in 12 sites, including six floodplain lakes, one backwater and five lotic sites (two channel and three rivers) in three sub-basins on the floodplain stretch of the upper Paraná River: Paraná subbasin (S1 and S3 - connected floodplain lakes, S2 - isolated floodplain lake and S4 - Paraná River), Baía sub-basin (S5 - connected floodplain lake, S6 - isolated floodplain lake, S7 - Curutuba channel and S8 - Baía River) and Ivinhema sub-basin (S9 - connected floodplain lake, S10 - isolated floodplain lake, S11 - Ipoitã channel and S12 - Ivinhema River) (Fig. 1).

\section{Sampling scheme and samples analysis}

Samplings were performed quarterly during the potamophase and limnophase periods between 2000 and 2011 (except in 2001 and 2003 when only two samples were taken in each year) as part of the Brazilian 'Long Term Ecological Research Program. Daily water level (WL) data for the Paraná River were obtained from Itaipu Binational (Itaipu Binacional), the National Water Agency (Agência Nacional das Águas - ANA) and the Limnology, Ichthyology and Aquaculture Research Center (Núcleo de Pesquisas em Ictiologia, Limnologia e Aquicultura Nupélia). As a reference, the flooding process of the Paraná and Baía sub-basins is considered to begin when the level of the Paraná River is above $3.5 \mathrm{~m}$, and the Paraná River is considered to influence the Ivinhema subbasin environments when its level is above 4.5 (Thomaz et al., 2004). The upper Paraná River hydrological regime comprises periods of drought from June to September, and floods from October to February (Dittrich et al., 2016). Extreme periods of drought occurred at the upper Paraná River during 2000 and 2001, which were influenced by La Niña, a climatic event responsible for negative anomalies in rainfall in the upper Paraná River (Borges and Train, 2009). Intense floods also occurred in 2005, 2007, 2010 and 2011, with the first three years influenced, even with less intensity, by climatic event El Niño, the presumable driver of positive rainfall anomalies recorded in this region (CPTEC, 2012). As our study did not aim to explain directly these climatic events, we can only speculate that these events seem to influence the precipitation levels and consequently the $\mathrm{WL}$ in this region. Besides that, the fragmentation of the Paraná River by upstream dams regulates the discharges and also influences the hydrosedimentological regime (Souza-Filho et al., 2004).

For each year, pulse attributes (limnophase and potamophase days and connectivity index) were estimated using the software PULSO (http://www.neiff.com.ar/ Neiff and Neiff, 2003). The limnophase amplitude is the number of days when the WL was lower than the refer- 
ence level, potamophase amplitude is the number of days when the WL was higher than the reference level, and connectivity index is the ratio of the number of days between the potamophase and limnophase performed to each year (Neiff, 1990).

Samples of phytoplankton were collected at the subsurface $(20 \mathrm{~cm})$ of the pelagic region of each site, and fixed with acetic Lugol's solution. Randomly selected fields were counted under an inverted microscope, according to Lund et al. (1958) and Utermöhl (1958) methods. The sedimentation of aliquot of the water sample (3, 5 or $10 \mathrm{~mL}$ ) was established according to the algae and debris concentration present in each sample, and the sed- imentation time according to the height of the sedimentation chamber, being at least three hours for each centimeter of height of the chamber (Margalef, 1983). The frequency of occurrence of the species $($ Constancy $=\mathrm{C}$ ) was calculated according to Dajoz (2005), being classified as constant $(\mathrm{C} \geq 70 \%)$, common $(30 \% \geq \mathrm{C} \leq 70 \%)$, sporadic $(10 \% \geq \mathrm{C} \leq 30 \%)$ or rare $(\mathrm{C} \leq 10 \%)$.

Alpha diversity was estimated according to the species richness, i.e., the number of taxa in each sample. Gamma diversity was estimated according to the total number of taxa in the study region (total and by period in each sub-basin) and nonparametric estimators of diversity (Chao, Jackknife 1 and 2, and Bootstrap) were

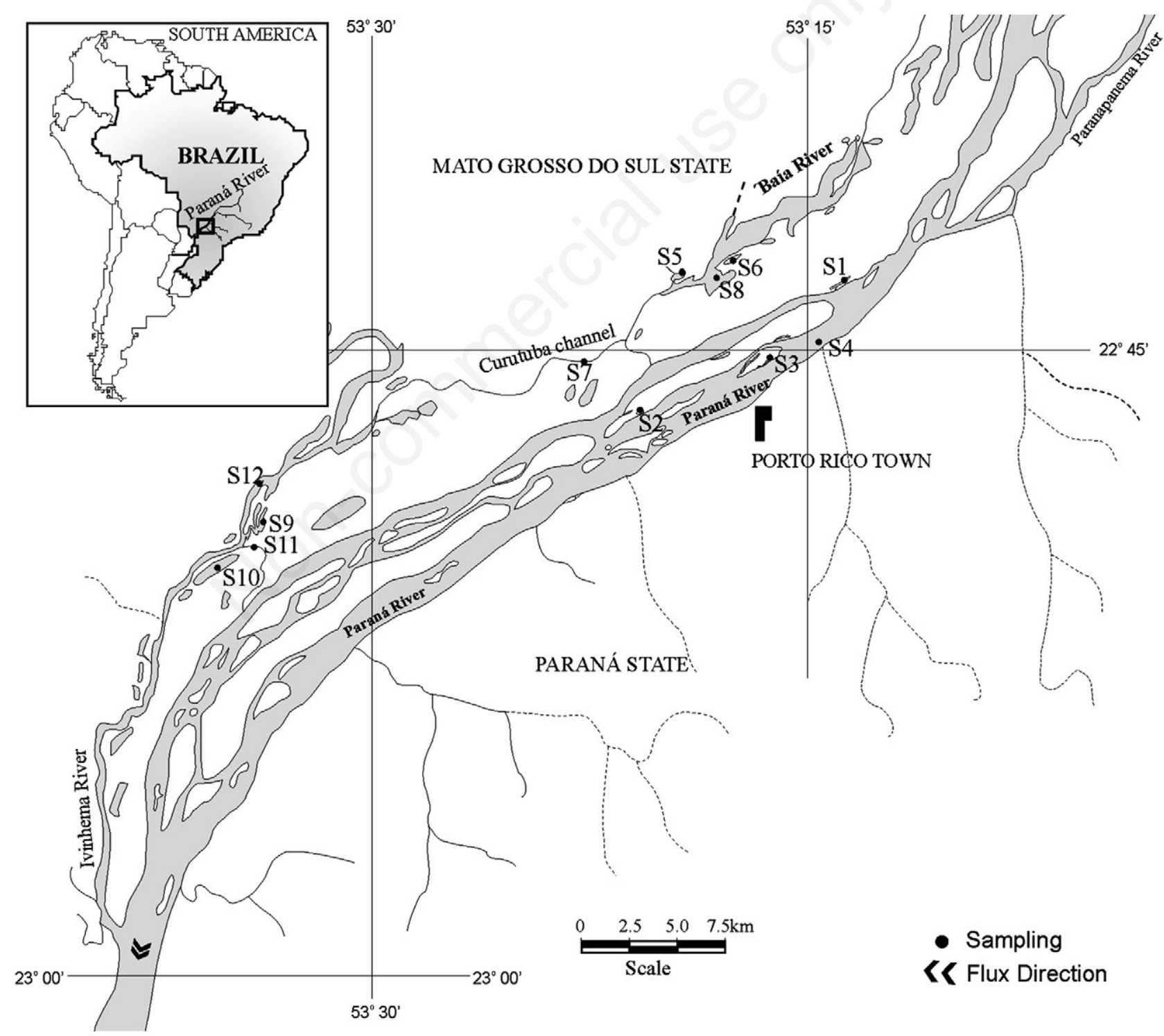

Fig. 1. Study area and sampling stations in the upper Paraná River floodplain. Paraná Sub-basin (S1 to S4); Baía sub-basin (S5 to S8); Ivinhema sub-basin (S9 to S12). 
using to verify if the gamma diversity registered was approaching of the expected diversity. The change in species composition (beta diversity) was estimated between all sites of the study region in each sampling, using the Sorensen's ( $\left.\beta_{\text {sor }}\right)$ and Simpson's $\left(\beta_{\text {sim }}\right)$ indexes. $\beta_{\text {sim }}$ is suitable for differentiating between turnover and nesting processes (Baselga, 2010).

The water temperature $\left(\mathrm{WT},{ }^{\circ} \mathrm{C}\right), \mathrm{pH}$, electric conductivity (EC, $\mu \mathrm{S} \mathrm{cm}^{-1}$ ), and dissolved oxygen (DO, mg $\mathrm{L}^{-1}$ ) data were obtained using Digimed portable digital potentiometers. Water column transparency $(\mathrm{m})$ was obtained using a Secchi disk, and the euphotic zone $\left(Z_{\text {eu, }}\right.$ m) was calculated as 2.7 times the depth of the Secchi disk (Cole, 1994). The soluble reactive phosphorus (SRP, $\mu \mathrm{g} \mathrm{L}^{-1}$; Golterman et al., 1978), nitrate $\left(\mathrm{NO}_{3}{ }^{-}, \mu \mathrm{g}\right.$ $\mathrm{L}^{-1}$; Giné et al., 1980), nitrite $\left(\mathrm{NO}_{2}^{-}, \mu \mathrm{g} \mathrm{L}^{-1}\right.$; Giné et al., $1980)$ and ammonium $\left(\mathrm{NH}_{4}^{+}, \mu \mathrm{g} \mathrm{L}{ }^{-1}\right.$; Koroleff, 1978) levels were determined. The dissolved inorganic nitrogen (DIN) was determined from the $\mathrm{NO}_{3}{ }^{-}, \mathrm{NO}_{2}{ }^{-}$and $\mathrm{NH}_{4}{ }^{+}$concentrations.

\section{Data analysis}

We first performed a Principal Component Analysis (PCA) to summarize the environmental variability at each sub-basin using the variables: WT, $\mathrm{pH}, \mathrm{DO}, \mathrm{EC}, \mathrm{Z}_{\mathrm{eu}}$, SRP, DIN, and WL. Additionally, a Detrended Correspondence Analysis (DCA) was used to summarize the phytoplankton composition data and evaluate the temporal and spatial differences in each sub-basin. A presence/absence matrix was used for the DCA analysis, and it included species in all the different environments and sample periods within each sub-basin. Analysis of variance (ANOVA) were applied in the following situations: to the scores from the first two PCA axes to test temporal (hydrological period) and spatial (isolated and connected lakes, and lotic sites) differences in limnological conditions; to the scores from the first two DCA axes to test temporal (year and hydrological period) and spatial (isolated and connected lakes, and lotic sites) differences in the phytoplankton composition within each sub-basin; to test spatial (isolated and connected lakes, and lotic sites) and temporal (year and hydrological period) differences in the alpha diversity; and to test temporal differences in the gamma (year and hydrological period) and beta (year and hydrological periods) diversity. The relationship among beta diversity ( $\beta_{\text {sor }}$ and $\beta_{\text {sim }}$ ), environmental heterogeneity represented by the coefficient of variation of the abiotic variables (WT, $\mathrm{pH}, \mathrm{DO}, \mathrm{EC}, \mathrm{Z}_{\mathrm{eu}}$, SRP and DIN) and water levels of the Paraná River in each sampling, was tested using Pearson's correlation coefficient. The PCA, DCA and ANOVA analyses were performed with the software R (R Core Team, 2012). Pearson's correlation coefficient was determined using the software Statistica (StatSoft, 2005).

\section{RESULTS}

\section{Water level, connectivity and environmental variability in the sub-basins}

Hydrosedimentological cycles in the Paraná River floodplain were characterized by extreme droughts in 2000 and 2001, and intense floods in 2005, 2007, 2010 and 2011 (Fig. 2). In the years 2007, 2009, 2010 and 2011 for both the Paraná and Baía sub-basins (reference level above $3.5 \mathrm{~m}$ ) and for the Ivinhema sub-basin (reference level above $4.5 \mathrm{~m}$ ) occurred more days under potamophase. The period of isolation of the lentic environments was longer for the Paraná and Baía sub-basins in 2001 and for the Ivinhema sub-basin in 2000, 2001 and 2004. At both the Paraná and Baía sub-basins, the highest connectivity index between lentic and lotic environments occurred in 2007, 2009, 2010 and 2011, whereas for the Ivinhema sub-basin, the highest connectivity index was observed in 2007 and 2010 (Tab. 1).

The first two PCA axes generated for the Paraná subbasin explained $49 \%$ of the environmental variability. The Axis 1 was correlated with SRP (0.14), DO (-0.48), pH ($0.47)$, DIN $(-0.45)$ and $Z_{\text {eu }}(-0.43)$, while the second axis was correlated with WT (0.64), WL (0.54) and DO ($0.19)$. For this sub-basin was verified different between sites (axis $1=\mathrm{P}<0.05$; axis $2=\mathrm{P}<0.05$ ) and hydrological periods (axis $1=\mathrm{P}<0.05$; axis $2=\mathrm{P}<0.05$ ) (Fig. 3a).

For the Ivinhema sub-basin, the first two PCA axes explained $50 \%$ of the variability. The axis 1 was correlated with WL (0.47) and DO (-0.53). The second axis was correlated with $Z_{\mathrm{eu}}(0.43)$ and SRP $(-0.58)$. For this sub-basin was verified different between sites (axis $1=$

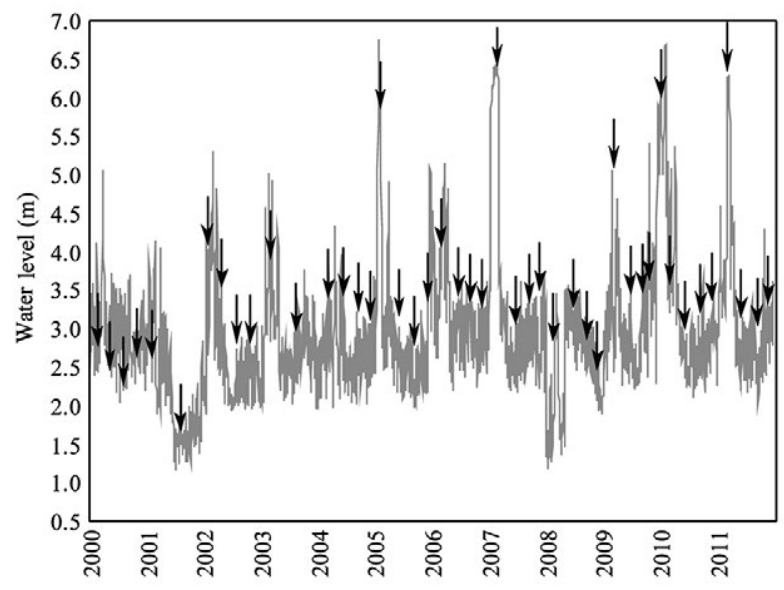

Fig. 2. Daily water levels of the Paraná River with their reference values for the flooding of the different sub-basins between the years 2000 and 2011. Arrows indicate sampling. 
$\mathrm{P}<0.05$; axis $2=\mathrm{P}<0.05$ ) and hydrological periods (axis $1=\mathrm{P}<0.05)$ (Fig. 3b).

In Baía sub-basin, 54\% of the variability was explained by the two first PCA axes. The first axis was correlated with WL (0.48), WT (0.45) and DO (-0.53). The second axis was correlated with SRP $(0.47)$ and $Z_{\text {eu }}$ $(-0.54)$. For this sub-basin, a discrete spatial separation, however significant (axis $1=\mathrm{P}<0.05$; axis $2=\mathrm{P}<0.05$ ) and a clear temporal separation (axis $1=\mathrm{P}<0.05$; axis $2=$ $\mathrm{P}<0.05$ ) were observed (Fig. 3c).

\section{Phytoplankton composition}

A total of 753 sub-generic taxa distributed among the following taxonomical groups were identified: Chlorophyceae (207), Bacillariophyceae (129), Cyanobacteria (124), Euglenophyceae (121), Zygnematophyceae (104), Xanthophyceae (28), Chrysophyceae (18), Cryptophyceae (10), Dinophyceae (10), Raphidophyceae (1) and Oedogoniophyceae (1). The genus Trachelomonas Ehrenberg had the highest number of taxa (60). High contribution of rare species was detected $(92 \%)$, whereas sporadic $(6 \%)$, frequent $(2 \%)$ and constant $(0.2 \%)$ species had low contributions to total of taxa. Constant species were just Cryptomonas marssonii Skuja and Chroomonas acuta Utermöhl, which had a frequency of occurrence (C) of $87 \%$ and $78 \%$, respectively (Tab. 2 ).

Chlorophyceae were mainly represented by Spermatozopsis exsultans Korshikov $(\mathrm{C}=48 \%)$ and Monoraphidium contortum (Thuret) Komàrková-Legnerová $(\mathrm{C}=40 \%)$. Bacillariophyceae were the second most represented group, and there was a high frequency of occurrence of

Tab. 1. Pulse attributes of daily water levels of the Paraná in the upper Paraná River floodplain for each year of the study, with influence on the Paraná, Baía and Ivinhema sub-basins.

\begin{tabular}{lcccccc} 
& \multicolumn{3}{c}{ Paraná and Báa } & \multicolumn{3}{c}{ Ivinhema } \\
& $\Sigma P P$ & $\Sigma L P$ & CI & $\Sigma P P$ & $\Sigma L P$ & $C I$ \\
2000 & 11 & 355 & 0.03 & 1 & 365 & 0.00 \\
\hline 2001 & 3 & 362 & 0.01 & 0 & 365 & 0.00 \\
\hline 2002 & 36 & 329 & 0.11 & 5 & 360 & 0.01 \\
\hline 2003 & 27 & 338 & 0.08 & 3 & 362 & 0.01 \\
\hline 2004 & 10 & 356 & 0.03 & 0 & 366 & 0.00 \\
\hline 2005 & 54 & 311 & 0.17 & 29 & 336 & 0.09 \\
\hline 2006 & 56 & 309 & 0.18 & 4 & 361 & 0.01 \\
\hline 2007 & 60 & 305 & 0.20 & 55 & 310 & 0.18 \\
\hline 2008 & 39 & 237 & 0.16 & 2 & 364 & 0.01 \\
\hline 2009 & 93 & 272 & 0.34 & 28 & 337 & 0.08 \\
\hline 2010 & 102 & 263 & 0.39 & 68 & 297 & 0.23 \\
\hline 2011 & 81 & 284 & 0.29 & 35 & 330 & 0.11
\end{tabular}

$C I$, connectivity index; $\Sigma P P$, number of days under potamophase; $\Sigma L P$, number of days under limnophase.
Aulacoseira granulata var. granulata (Ehrenberg) Simonsen $(\mathrm{C}=52 \%)$, A. granulata var. angustissima (O.F. Müller) Simonsen $(C=36 \%)$ and Aulacoseira distans (Ehrenberg) Simonsen $(C=41 \%)$. Cyanobacteria were mainly represented by Synechocystis aquatilis Sauvageau
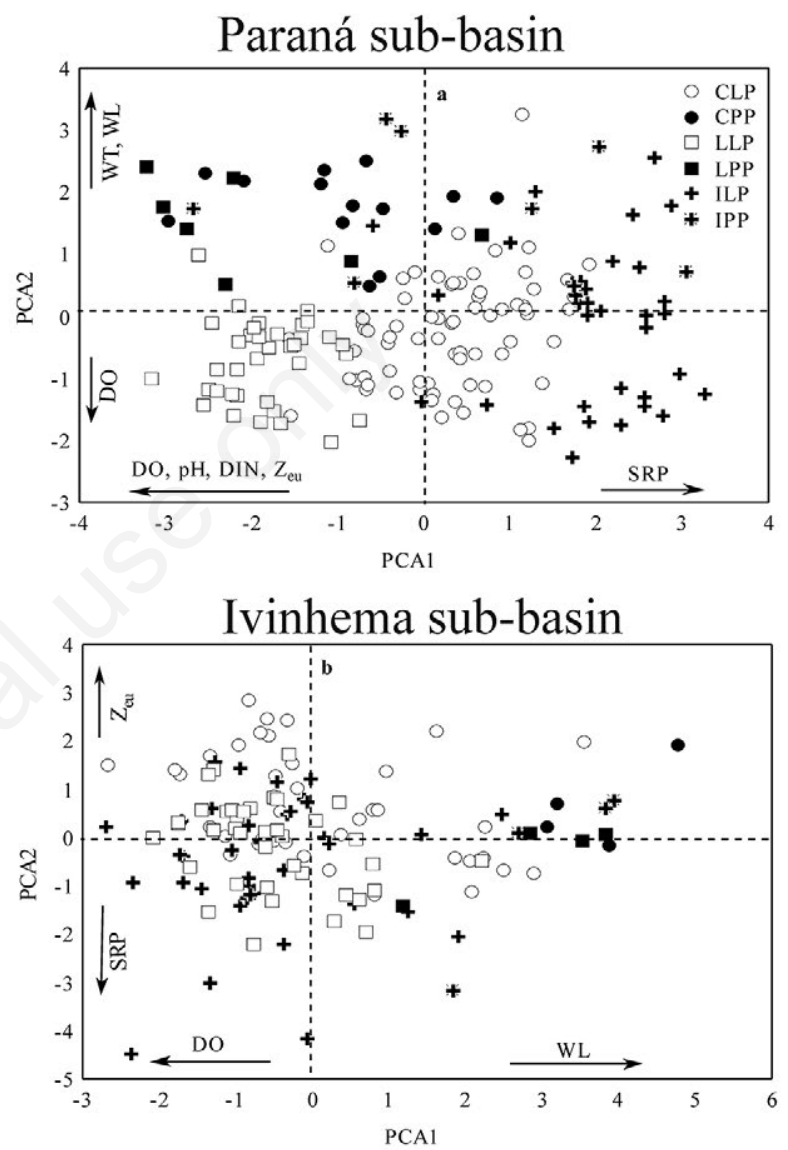

Baía sub-basin

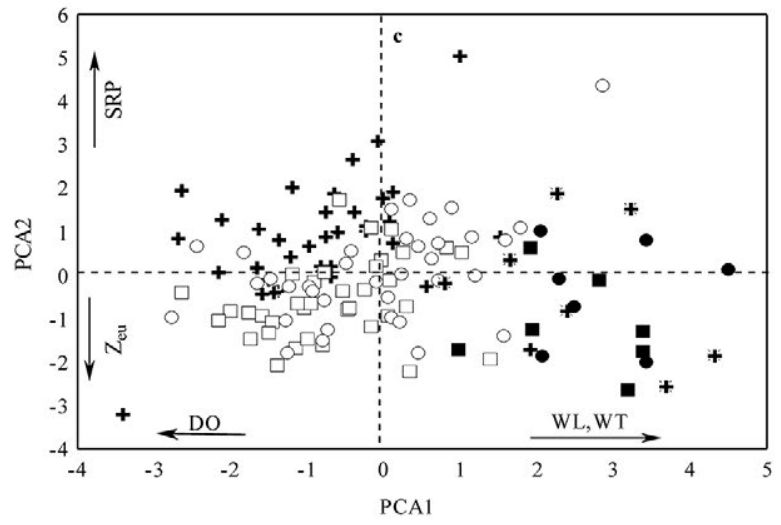

Fig. 3. Ordination of the first two axes of Principal Component Analysis for the sub-basins: a) Paraná, b) Ivinhema, c) Baía. CLP, connected lake in limnophase; CPP, connected lake in potamophase; LLP, lotic in limnophase; LPP, lotic in potamophase; ILP, isolated lake in limnophase; IPP, isolated lake in potamophase. 
Tab. 2. Frequency of occurrence of constant, frequent and sporadic phytoplankton species in the upper Paraná River floodplain (asterisk indicates the occurrence). Rare species $(\mathrm{C} \leq 10 \%)$ are not included.

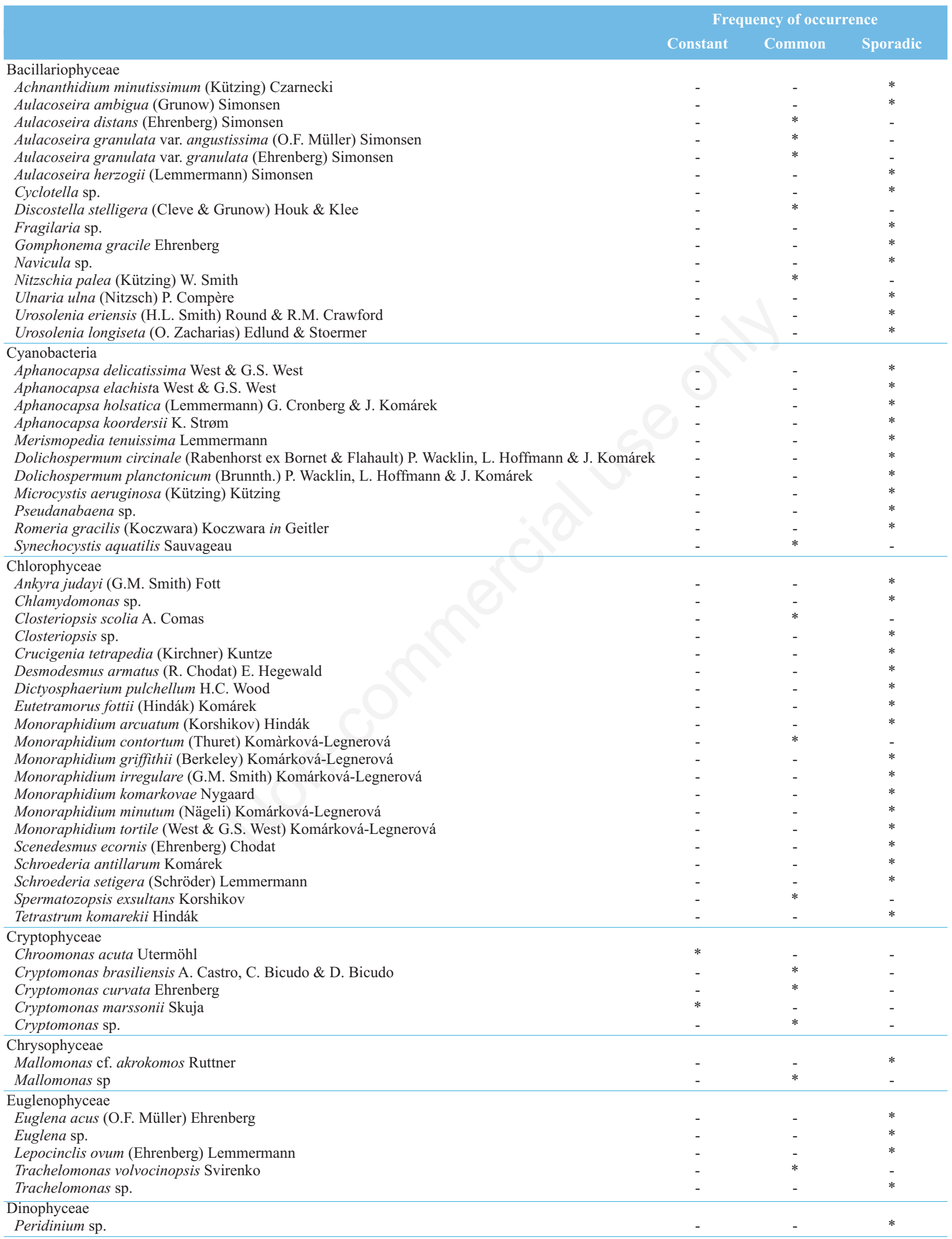


(C=37\%), Dolichospermum planctonicum (Brunnth.) Wacklin, L. Hoffm. \& Komárek $(\mathrm{C}=25 \%)$ and Merismopedia tenuissima Lemmermann $(\mathrm{C}=24 \%)$, and Euglenophyceae were mainly represented by Trachelomonas volvocinopsis Svirenko (C=30\%).

The DCA showed discreet spatial and temporal differences in phytoplankton composition for Paraná (axis $1=$ 0.29 and axis $2=0.28$ ), Ivinhema (axis $1=0.42$ and axis $2=0.28$ ) and Baía sub-basins (axis $1=0.28$ and axis $2=$ 0.20). A spatial variation was observed for the Paraná River and was primarily related to the presence of Cryptophyceae, Cyanobacteria and Bacillariophyceae (Fig. 4ab). In the limnophase, the Ivinhema River and Ipoitã channel were separated from the others, which was primarily related to presence of Bacillariophyceae (Fig. 4cd) and for Baía sub-basin, the DCA distinguished the Baía River in limnophase due to presence of Chlorophyceae, Bacillariophyceae and Euglenophyceae (Fig. 4e-f).

The ANOVA evidenced spatial and temporal differences for the first two DCA axes for phytoplankton composition in Paraná and Ivinhema sub-basins and only temporal differences in the Baía sub-basin (Tab. 3).

\section{Phytoplankton diversity}

Was recorded high gamma diversity in the upper Paraná River floodplain, being the higher values recorded

Tab. 3. ANOVA three-way results for phytoplankton composition data represented by the scores of the first two axes of the DCA.

\begin{tabular}{|c|c|c|c|c|}
\hline Variable & Effect & df & F & $\mathbf{P}$ \\
\hline DCA 1 & $\begin{array}{l}\text { Environment } \\
\text { Period }\end{array}$ & $\begin{array}{l}2 \\
1 \\
1 \\
2 \\
2 \\
1 \\
2\end{array}$ & $\begin{array}{c}25.5067 \\
12.2694 \\
313.9687 \\
0.4293 \\
2.7425 \\
12.7011 \\
0.1471\end{array}$ & $\begin{array}{l}<0.05 \\
<0.05 \\
<0.05 \\
0.6516 \\
0.0673 \\
<0.05 \\
0.8632\end{array}$ \\
\hline DCA 2 & $\begin{array}{l}\text { Environment } \\
\text { Period } \\
\text { Year } \\
\text { Environment } * \text { Period } \\
\text { Environment } * \text { Year } \\
\text { Period *Year } \\
\text { Environment } * \text { Period *Year }\end{array}$ & $\begin{array}{l}2 \\
1 \\
1 \\
2 \\
2 \\
1 \\
2\end{array}$ & $\begin{array}{c}26.6071 \\
1.6371 \\
8.9708 \\
0.2553 \\
5.9638 \\
0.2825 \\
0.3883\end{array}$ & $\begin{array}{l}<0.05 \\
0.2025 \\
<0.05 \\
0.7749 \\
<0.05 \\
0.5957 \\
0.6788\end{array}$ \\
\hline DCA 1 & $\begin{array}{l}\text { Environment } \\
\text { Period } \\
\text { Year } \\
\text { Environment *Period } \\
\text { Environment *Year } \\
\text { Period *Year } \\
\text { Environment *Period *Year }\end{array}$ & $\begin{array}{l}3 \\
1 \\
1 \\
2 \\
3 \\
1 \\
2\end{array}$ & $\begin{array}{c}4.9065 \\
34.8999 \\
28.3088 \\
1.7633 \\
0.2652 \\
2.4055 \\
0.2416\end{array}$ & $\begin{array}{l}<0.05 \\
<0.05 \\
<0.05 \\
0.1747 \\
0.8503 \\
0.1228 \\
0.7856\end{array}$ \\
\hline DCA 2 & $\begin{array}{l}\text { Environment } \\
\text { Period } \\
\text { Year } \\
\text { Environment *Period } \\
\text { Environment } * \text { Year } \\
\text { Period *Year } \\
\text { Environment } * \text { Period *Year }\end{array}$ & $\begin{array}{l}3 \\
1 \\
1 \\
2 \\
3 \\
1 \\
2\end{array}$ & $\begin{array}{c}14.3651 \\
12.8189 \\
18.7539 \\
1.7525 \\
1.8503 \\
0.1457 \\
2.5546\end{array}$ & $\begin{array}{l}<0.05 \\
<0.05 \\
<0.05 \\
0.1766 \\
0.1401 \\
0.7031 \\
0.0808\end{array}$ \\
\hline DCA 1 & $\begin{array}{l}\text { Environment } \\
\text { Period } \\
\text { Year } \\
\text { Environment *Period } \\
\text { Environment } * \text { Year } \\
\text { Period *Year } \\
\text { Environment *Period *Year }\end{array}$ & $\begin{array}{l}2 \\
1 \\
1 \\
2 \\
2 \\
1 \\
2\end{array}$ & $\begin{array}{c}1.2559 \\
1.8654 \\
63.7542 \\
0.8193 \\
0.4928 \\
3.2826 \\
0.0969\end{array}$ & $\begin{array}{l}0.2875 \\
0.1738 \\
<0.05 \\
0.4425 \\
0.6118 \\
0.0718 \\
0.9077\end{array}$ \\
\hline DCA 2 & $\begin{array}{l}\text { Environment } \\
\text { Period } \\
\text { Year } \\
\text { Environment *Period } \\
\text { Environment *Year } \\
\text { Period *Year } \\
\text { Environment *Period *Year }\end{array}$ & $\begin{array}{l}2 \\
1 \\
1 \\
2 \\
2 \\
1 \\
2\end{array}$ & $\begin{array}{l}0.3005 \\
6.2615 \\
1.1760 \\
1.1440 \\
0.7896 \\
2.6670 \\
1.1190\end{array}$ & $\begin{array}{l}0.7408 \\
<0.05 \\
0.2797 \\
0.3210 \\
0.4557 \\
0.1043 \\
0.3290\end{array}$ \\
\hline
\end{tabular}

df, degrees of freedom; $F$, statistical value $F$; Environment, connected lake, isolated lake, channel and river; Period, limnophase and potamophase, Year, 2000-2011; statistical significance level at $P<0.05$. 


\section{Paraná sub-basin}
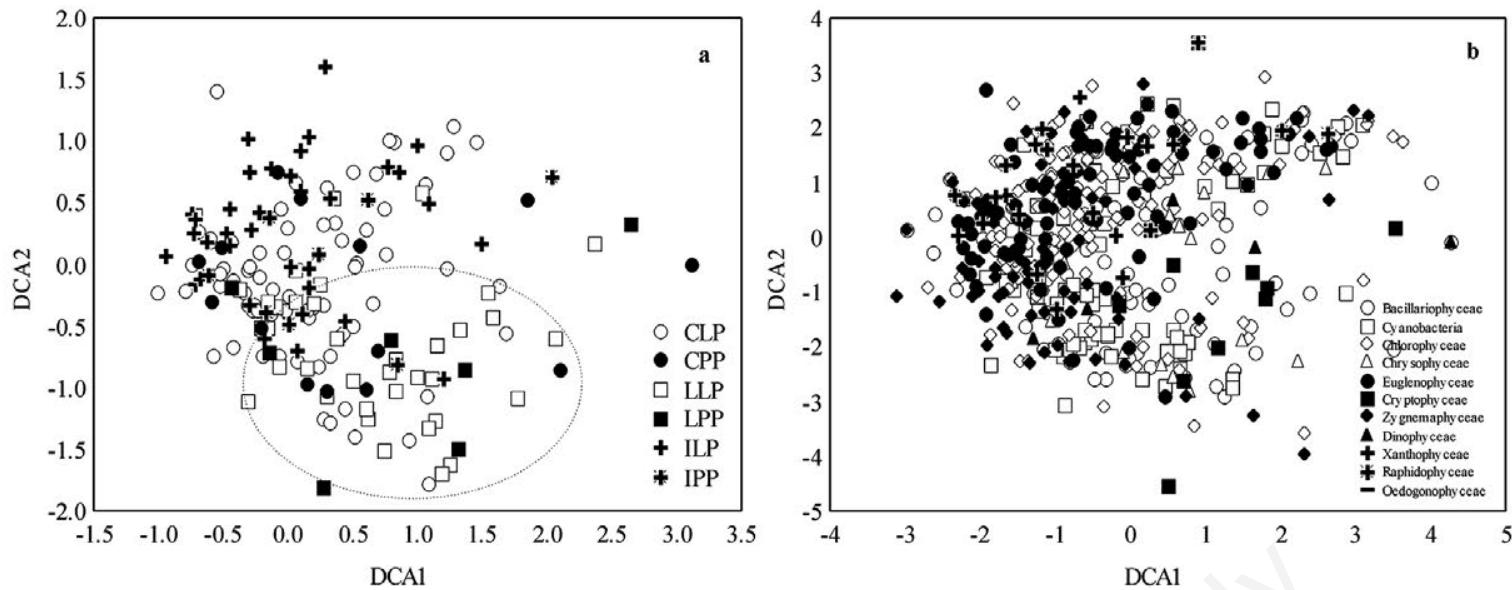

Ivinhema sub-basin
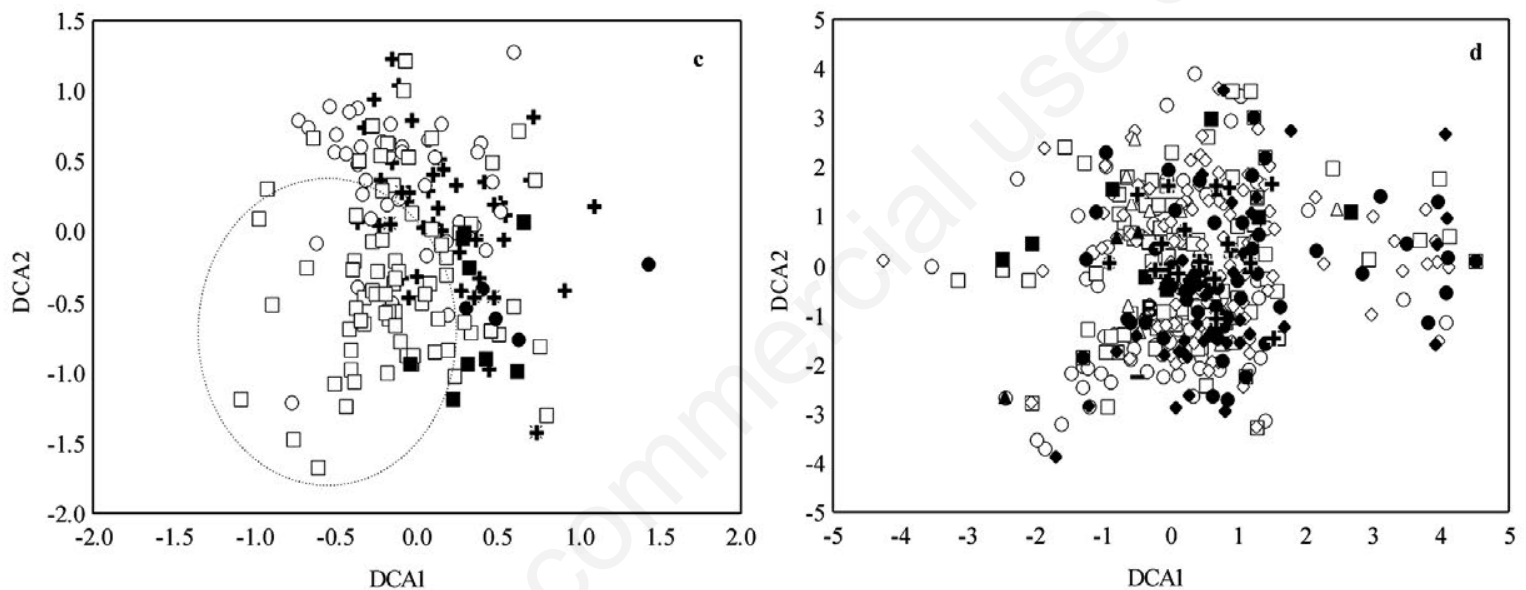

Baía sub-basin
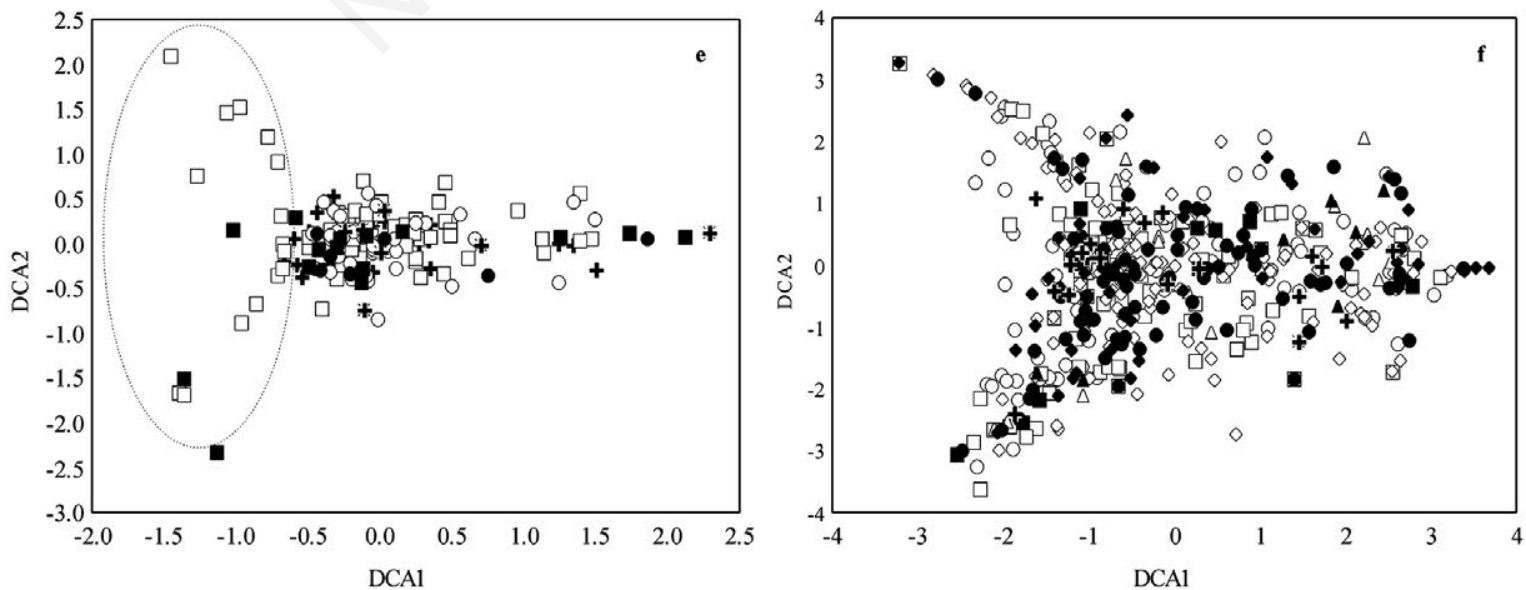

Fig. 4. Dispersion of scores over the first two axes of Detrended Correspondence Analysis for the sub-basins: a-b) Paraná, c-d) Ivinhema, e-f) Baía. CLP, connected lake in limnophase; CPP, connected lake in potamophase; LLP, lotic in limnophase; LPP, lotic in potamophase; ILP, isolated lake in limnophase; IPP, isolated lake in potamophase. 
in limnophase, and the lowest in potamophase in all subbasins, with significant differences $(\mathrm{P}>0.05)$. In relation to the 12 years of study, the highest gamma diversity was recorded in 2007 (343 taxa), and the lowest in 2001 (206 taxa), however without significant differences $(\mathrm{P}<0.05)$. The bootstrap estimator best reflected the gamma diversity, which produced values always above $80 \%$ of the values recorded throughout the entire study period (Tab. 4).

The highest mean alpha diversity values were observed in 2002 in Paraná sub-basin and in 2007 at both the Ivinhema and Baía sub-basins (Fig. 5a). The highest mean alpha diversity values occurred in connected lakes, followed by isolated lakes and the lowest values were recorded in lotic environments (Fig. 5b). The highest mean alpha diversity values in Paraná sub-basin occurred in the isolated lakes, whereas in Baía and Ivinhema subbasins, such values were recorded in connected lakes (Fig. 5c). Overall, the highest mean alpha diversity values during the potamophase occurred in sites of Paraná sub-basin, followed by the Baía and Ivinhema sub-basins, while in the limnophase, the highest values were observed in sites of Baía sub-basin, followed by the Ivinhema and Paraná sub-basins (Fig. 5d). Significant differences in alpha diversity were verified among sites $(\mathrm{P}<0.05)$, hydrological periods $(\mathrm{P}<0.05)$, and years $(\mathrm{P}<0.05)$.

Between the lakes, the S2 (398 taxa), S5 (390 taxa) and S1 (382 taxa) had the highest total taxa number, whereas between lotic sites, the Baía River (289 taxa) had the highest total taxa number. Between the sub-basins, The Paraná sub-basin had the highest phytoplankton taxa (567), followed by the sub-basins of Baía (547) and Ivinhema (492).

The beta diversity presented high values $\left(>0.83\right.$ to $\mathrm{B}_{\text {sor }}$ and $>0.72$ to $B_{\text {sim }}$ ) at both the potamophase and limnophase throughout the study period. The years 2001 (extreme drought) and 2011 (intense flood), presented the highest beta diversity $\left(\mathrm{B}_{\mathrm{sor}}=0.85\right.$ for both), and highest species turnover $\left(B_{\text {sim }}=0.80\right)$ in 2011. In relation to each sampling, the highest beta diversity $\left(\mathrm{B}_{\text {sor }}=0.91\right)$ occurred in March 2010 in the potamophase, and the lowest in May 2002 in the limnophase $\left(B_{\text {sor }}=0.83\right)$. The highest species turnover $\left(\mathrm{B}_{\mathrm{sim}}=0.85\right)$ occurred in March 2006 in the potamophase, and the lowest turnover in May 2002 in the limnophase $\left(B_{\text {sim }}=0.72\right)$. Significant differences for beta

Tab. 4. Gamma diversity registered among periods (limnophase and potamophase) for each sub-basin and years (2000-2011), and gamma diversity expected through of the nonparametric estimators (Chao, Jackknife 1 and 2, and Bootstrap) and their relative contributions (\%) in each period and year.

\begin{tabular}{|c|c|c|c|c|c|}
\hline & $\begin{array}{l}\text { Gamma } \\
\text { diversity } \\
\text { observed }\end{array}$ & $\mathbf{S}_{\text {chao }}$ & $\mathrm{S}_{\text {jacknife1 }}$ & $\mathrm{S}_{\text {jacknife2 }}$ & $\mathbf{S}_{\text {bootstrap }}$ \\
\hline & & & Period & & \\
\hline \multicolumn{6}{|l|}{ Paraná } \\
\hline Limnophase & 543 & $691.3(78.54 \%)$ & $705.8(76.93 \%)$ & $779.4(69.66 \%)$ & $618.3(87.82 \%)$ \\
\hline Potamophase & 277 & $459.2(60.32 \%)$ & $408.3(67.84 \%)$ & $490.9(56.42 \%)$ & $333.8(82.98 \%)$ \\
\hline \multicolumn{6}{|l|}{ Baía } \\
\hline Limnophase & 498 & $707.1(70.42 \%)$ & $664.8(74.90 \%)$ & $764.9(65.10 \%)$ & $571.6(87.12 \%)$ \\
\hline Potamophase & 313 & $471.5(66.38 \%)$ & $446.2(70.14 \%)$ & $522.6(59.89 \%)$ & $371.9(84.16 \%)$ \\
\hline \multicolumn{6}{|l|}{ Ivinhema } \\
\hline Limnophase & 442 & $617.1(71.62 \%)$ & $590.1(74.90 \%)$ & $675.2(65.46 \%)$ & $507.7(87.05 \%)$ \\
\hline Potamophase & 238 & $444.9(53.49 \%)$ & $363.4(65.49 \%)$ & $448.1(53.11 \%)$ & $291.1(81.75 \%)$ \\
\hline \multicolumn{6}{|c|}{ Years } \\
\hline 2000 & 275 & $385.0(71.40 \%)$ & $385.6(71.30 \%)$ & $439.5(62.60 \%)$ & $324.9(84.60 \%)$ \\
\hline 2001 & 206 & $351.7(58.60 \%)$ & $302.7(68.00 \%)$ & $364.6(56.50 \%)$ & $247.5(83.20 \%)$ \\
\hline 2002 & 259 & $358.9(72.20 \%)$ & $343.2(75.50 \%)$ & $390.9(66.30 \%)$ & $296.1(87.50 \%)$ \\
\hline 2003 & 260 & $387.6(67.10 \%)$ & $368.2(70.60 \%)$ & $428.0(60.70 \%)$ & $308.2(84.30 \%)$ \\
\hline 2004 & 312 & $432.4(72.10 \%)$ & $422.6(73.80 \%)$ & $481.2(64.80 \%)$ & $362.2(86.10 \%)$ \\
\hline 2005 & 298 & $383.5(77.70 \%)$ & $392.9(75.80 \%)$ & $434.3(68.60 \%)$ & $342.3(87.10 \%)$ \\
\hline 2006 & 307 & $392.1(78.30 \%)$ & $417.6(73.50 \%)$ & $455.5(67.40 \%)$ & $359.3(85.40 \%)$ \\
\hline 2007 & 343 & $473.5(72.40 \%)$ & $462.4(74.20 \%)$ & $525.9(65.20 \%)$ & $396.8(86.40 \%)$ \\
\hline 2008 & 238 & $356.3(66.80 \%)$ & $327.1(72.80 \%)$ & $381.4(62.40 \%)$ & $277.3(85.80 \%)$ \\
\hline 2009 & 242 & $328.0(73.80 \%)$ & $325.2(74.40 \%)$ & $367.2(65.90 \%)$ & $280.0(86.40 \%)$ \\
\hline 2010 & 302 & $480.6(62.80 \%)$ & $434.1(69.60 \%)$ & $515.7(58.60 \%)$ & $359.3(84.00 \%)$ \\
\hline 2011 & 295 & $490.5(60.10 \%)$ & $429.1(68.70 \%)$ & $515.4(57.20 \%)$ & $352.6(83.70 \%)$ \\
\hline Total & 753 & $890.3(84.60 \%)$ & $911.6(82.60 \%)$ & $978.6(76.90 \%)$ & $828.1(90.90 \%)$ \\
\hline
\end{tabular}


diversity were verified between the years $\left(B_{\text {sor }}-p<0.05\right.$ and $\mathrm{B}_{\text {sim }}-\mathrm{P}<0.05$ ) but not between limnophase and potamophase $\left(\mathrm{B}_{\text {sor }}-\mathrm{P}>0.05\right.$ and $\left.\mathrm{B}_{\text {sim }}-\mathrm{P}>0.05\right)$. In addition, were not found significant correlations between the WL of the Paraná River and beta diversity (Fig. 6a-b), as well as between the beta diversity and coefficients of variation of the abiotic variables, except a weak correlation between $\mathrm{B}_{\text {sim }}$ and conductivity $(\mathrm{r}=-0.33)$.

\section{DISCUSSION}

The results obtained through this long-term study showed that different hydrosedimentological cycles, represented by variability of water level and environmental heterogeneity, are determinants on phytoplankton composition and diversity in the floodplain. Fluctuations in WLs in the main channels are fundamental to structure, func- tion and integrity of the surrounding floodplain environments (Leira and Cantonati, 2008). Lateral habitats may be flooded over short- or long-term periods, which were reflected in the interannual variability of the potamophase and limnophase amplitude in this floodplain. Disturbance intensity is closely related to the intensity, frequency and amplitude of the different phases as well as to the degree of connectivity in the lakes (Neiff, 2001). The synergistic action of these attributes affected the different habitats and phytoplankton community in the Upper Paraná River floodplain. The high potamophase amplitudes detected in 2005, 2007, 2009, 2010 and 2011 were contrasted with the lowest amplitudes recorded in 2000 and 2001. Therefore, the connectivity indexes showed limnological differences between the twelve hydrosedimentological cycles and influenced mainly the phytoplankton composition and alpha and gamma diversity.

The high interannual variability of the phytoplankton
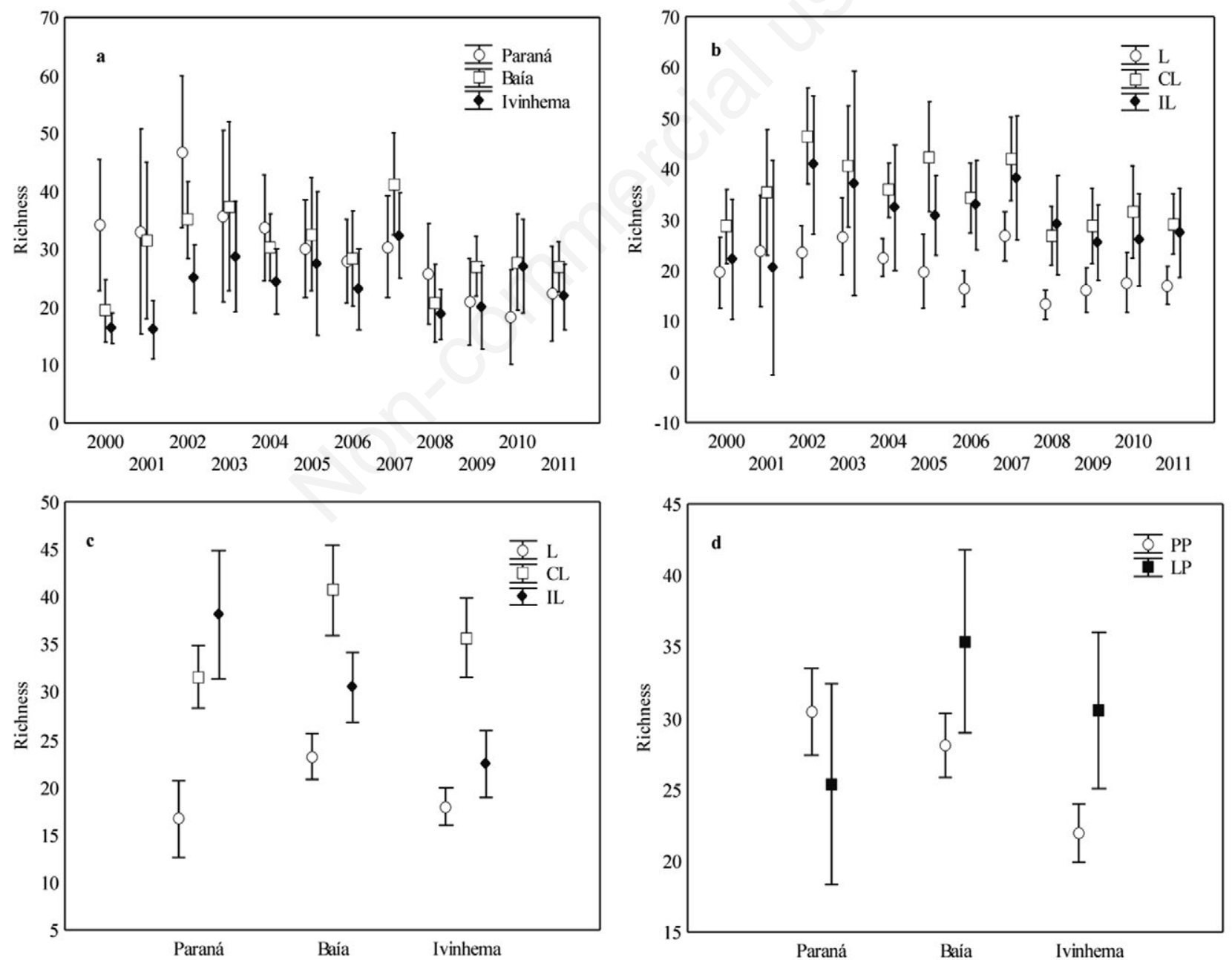

Fig. 5. Mean values and standard deviation of alpha phytoplankton diversity in the sites of the three sub-basins and periods between 2000 and 2011 in the upper Paraná River floodplain. CL, connected lake; IL, isolated lake; L, lotic; LP, limnophase; PP, potamophase. 
composition was reflected by frequency of occurrence of species, with high contribution of rare species. Chlorophyceae presented the highest species richness, as reported in other studies of this floodplain (Train and Rodrigues, 1998, 2004; Bovo-Scomparin and Train, 2008; Borges and Train, 2009; Rodrigues et al., 2009, 2015; Bortolini et al., 2014, 2016a, 2016b), and it was mainly represented by cosmopolitan species. The Chlorophyceans are likely favored by the environmental conditions of limnophase periods (e.g. light and nutrient availability), that are common in this floodplain, besides their ecophysiological adaptations, which ensure that Chlorophyceae are successful in inland waters. Despite the high phytoplankton diversity, only C. marssonii and C. acuta were constant over time. These cryptophyceans are opportunists and mixotrophics organisms with a high
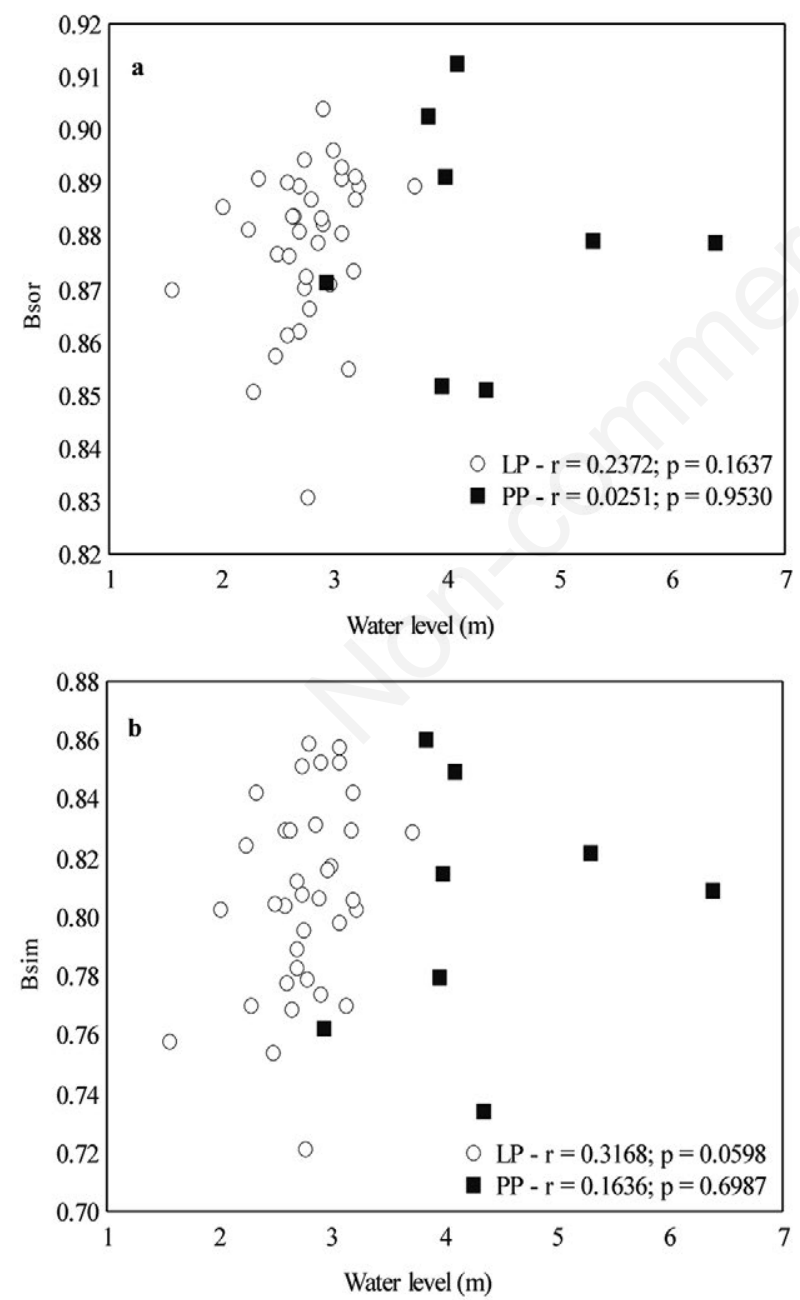

Fig. 6. Relationship between beta diversity, a) $B_{\text {sor }}$; b) $B_{\text {sim }}$, and water levels of the Paraná River. LP, limnophase; PP, Potamophase; $r$, $r$ of Pearson; $p$, significance level $=\mathrm{P}<0.05$ ). surface/volume ratio and high metabolism (Reynolds, 1998; Reynolds et al., 2002; Padisák et al., 2009) that most likely favor their permanence.

The spatial and temporal variability of species diversity illustrate the fundamental role of the sampling frequency for understanding ecological systems (Interlandi and Kilham, 2001) especially in a long-term. The high species diversity in floodplains is also related to the regional pool of species (Pinto et al., 2015) in these ecosystems. Therefore, the high phytoplankton gamma diversity detected in this floodplain is a result of interactions between the structural heterogeneity of environments (isolated and connected lakes, and lotic sites) with different resources available (e.g., nutrient, light), and the ability of planktonic algae to exploit such resources in each environment.

Although the gamma diversity presented significant differences between the hydrological periods, with higher values in the limnophase, and not between years, from a broader perspective, the highest gamma diversity recorded in 2007 may be related to intense potamophase and high hydrological connectivity in this year, which probably favored dispersion and exchange of phytoplankton innocula among sites, and later in low water level periods, these innocula are able to develop. In the other side, in 2001, a long limnophase (more than 360 days) associated with low connectivity prevailed and the lowest gamma diversity was recorded, probably limiting the dispersion and input of innocula in the sites of floodplain. Thus, these results confirm that regional-scale process, as the potamophase, contribute for the maintenance of local diversity (Ricklefs, 1987), and corroborate that the phytoplankton diversity can be favored, even if indirectly, with flooding and high WLs.

Alpha diversity was related to local and regional characteristics, resulting from hydrodynamic, chemical and biological variations (Borges and Train, 2009; Rodrigues et al., 2009; Bortolini et al., 2014), especially in the variations in the WL and environmental heterogeneity. The low mean alpha diversity values detected in lotic sites of the floodplain have been related to the greater instability of these lotic environments as well as to the greater flow velocity and lower water retention time (Train and Rodrigues, 2004). However, the highest mean values of phytoplankton richness founded in lakes connected, indicate the importance of the degree of connectivity between lakes and rivers as drivers of high phytoplankton richness in the upper Paraná River floodplain due to the easier exchange of innocula.

Previous studies have described human-induced degradation of the Paraná River and changes in limnological conditions over the last two decades, including degradation resulting from several dams built upstream of the study area, especially the Porto Primavera Dam (Souza 
Filho et al., 2004; Souza Filho, 2009; Roberto et al., 2009; Rodrigues et al., 2009, 2015). Thereby, a clear decrease in phytoplankton alpha diversity in the main channel of the Paraná River has been documented and associated with alterations in transparency, nitrogen and phosphorus forms (Rodrigues et al., 2015), as well as previous reports about the seston retention and sedimentation in the reservoir cascade upstream of the study site and high discharge rates (Roberto et al., 2009; Bovo-Scomparin et al., 2013). Despite this, the Paraná sub-basin still maintains high phytoplankton diversity, as seen in this study, due to the contribution of its associated lakes, which constituted, therefore, an important pool of species for this sub-basin, as well as for the floodplain as a whole. The establishment of phytoplankton species requires satisfactory conditions that allow them to disperse to a certain site and suitable environmental conditions for species survival and development (Reynolds et al., 2012), including nutrient availability, light incidence and water column mixing.

The high beta diversity values observed in both the limnophase and potamophase, although without correlation with the abiotic variables related to hydrosedimentological regime of the upper Paraná River, may be related to other factors that not measured in our study. In addition, the absence of correlation between beta diversity and WLs of the Paraná River, unlike what is expected, with the homogenizing effect on aquatic communities (Thomaz et al., 2007), is similar to other studies. Greater beta diversity in periods of higher WLs has been observed to phytoplankton also in the Araguaia River (Nabout et al., 2007) and Amazon River lowlands (Nogueira et al., 2010). Moreover, Simões et al., (2013) reported that the zooplankton beta diversity was similar in an atypical dry year (2000) and in a year with a typical flood pulse (2010) in the upper Paraná River floodplain, as well as Dittrich et al., (2016) for fishes, macrophytes and zooplankton in a long-term study in this same floodplain. Borges and Train (2009) recorded dissimilarities in phytoplankton composition among habitats in this system but in their publication, only two years without potamophase were analyzed. Our results disagree Pinto et al. (2015) who observed greater beta diversity during the limnophase in the Pampean floodplain. This finding may be explained by the great length of the upper Paraná River as well as by the mosaic of habitats occurring in its floodplain, with distinct geomorphological and limnological characteristics and different degrees of anthropogenic action.

\section{CONCLUSIONS}

Our findings demonstrate that the variability in the hydrosedimentological cycles represented by water level variability and by conspicuous pattern of mosaic of habitats in this floodplain, are essential for sustaining phyto- plankton diversity and ecosystem integrity. The hydrosedimentological regime of the upper Paraná River although it is regulated indirectly by climatic events that influence rainfall levels in the region, as well as by the operation of upstream dams, is an important factor in local and regional scale and must be sustained by the protection or restoration of natural hydrological regimes. This approach is relevant and proved be useful to understand floodplain systems and associated phytoplankton community, essential for management efforts and for conservation strategies.

\section{ACKNOWLEDGMENTS}

The authors are grateful to the Núcleo de Pesquisas em Limnologia, Ictiologia e Aquicultura (Nupélia) at Universidade Estadual de Maringá for logistic support; Conselho Nacional de Pesquisa e Desenvolvimento - CNPq / Long-Term Ecological Research Program (LTER) for financial support; Coordenação de Aperfeiçoamento de Pessoal de Nível Superior - CAPES for a scholarship granted to the first author. We thank to Nupélia's Limnology laboratory by assistance with physical and chemical variables of water.

\section{REFERENCES}

Agostinho AA, Thomaz SM, Gomes LC, 2005. Conservation of the biodiversity of Brazil's inland waters. Conserv. Biol. 19:646-652.

Amoros C, Bornette G, 2002. Connectivity and biocomplexity in waterbodies of riverine floodplains. Freshwater Biol. 47:761-776.

Baselga A, 2010. Partitioning the turnover and nestedness components of beta diversity. Glob. Ecol. Biogeogr. 19:134-143.

Bonecker CC, Simões NR, Minte-Vera CV, Lansac-Tôha FA, Velho LFM, Agostinho AA, 2013. Temporal changes in zooplankton species diversity in response to environmental changes in an alluvial valley. Limnologica 43:114-121.

Borges PAF, Train S, 2009. Phytoplankton diversity in the Upper Paraná River floodplain during two years of drought (2000 and 2001). Braz. J. Biol. 69:637-647.

Bortolini JC, Bovo-Scomparin VM, De Paula ACM, Moresco GA, Reis LM, Jati S, Rodrigues LC, 2014. Composition and species richness phytoplankton in a subtropical floodplain lake: a long-term study. Acta Limnol. Brasil. 26:296-305.

Bortolini JC, Train S, Rodrigues LC, 2016a. Extreme hydrological periods: effects on phytoplankton variability and persistence in the subtropical floodplain. Hydrobiologia 763:223-236.

Bortolini JC, Moresco GA, Paula ACM, Jati S, Rodrigues LC, 2016b. Functional approach based on morphology as a model of phytoplankton variability in a subtropical floodplain lake: a long-term study. Hydrobiologia 767:151-163.

Bovo-Scomparim VM, Train S, 2008. Long-term variability of the phytoplankton community in an isolated floodplain lake 
of the Ivinhema River State Park, Brazil. Hydrobiologia 610:331-344.

Bovo-Scomparim VM, Train S, Rodrigues LC, 2013. Influence of reservoirs to dispersion and seasonal variation of the phytoplankton community in the Upper Paraná River, Brazil. Hydrobiologia 702:115-127.

Cole GA, 1994. Textbook of limnology. Waveland Press Inc., Long Grove: 412 pp.

CPTEC (Centro de Previsão do tempo e estudos climáticos), 2012. [Web site in Portuguese]. Available from: http://www.cptec.inpe.br/

Dajoz R, 2005. [Princípios de ecologia].[Book in Portuguese]. Artmed, Porto Alegre: 520 pp.

Dittrich J, Dias JD, Bonecker CC, Lansac-Tôha FA, Padial AA, 2016. Importance of temporal variability at different spatial scales for diversity of floodplain aquatic communities. Freshwater Biol. 61:316-327.

Giller PS, Hillebrand H, Berninger UG, Gessner MO, Hawkins S, Inchausti P, Inglis I, Leslie H, Malmqvist B, Monaghan MT, Morin PJ, O’Mullan G, 2004. Biodiversity effects on ecosystem functioning: emerging issues and their experimental test in aquatic environments. Oikos 104:423-436.

Giné MF, Bergamim H, Zagatto EAG, Reis BF, 1980. Simultaneus determination of nitrite and nitrate by flow injection analysis. Anal. Chim. Acta 114:191-197.

Golterman HL, Clymo RS, Ohstad MA, 1978. Methods for physical and chemical analysis of freshwater. Blackwell Scientific Publ., Oxford: 213 pp.

Interlandi SJ, Kilham SS, 2001. Limiting resources and the regulation of diversity in phytoplankton communities. Ecology 82:1270-1282.

Koroleff K, 1978. Determination of ammonia, p. 175-180. In: K. Grasshoff and E. Kremling (eds.), Methods of seawater analysis. Verlag Chemie, Winhein.

Leira M, Cantonati M, 2008. Effects of water-level fluctuations on lakes: an annotated Bibliography. Hydrobiologia 613:171-184.

Legendre P, Borcard D, Peres-Neto PR, 2005. Analyzing beta diversity: partitioning the spatial variation of community composition data. Ecol. Monogr. 75:435-450.

Lund JWG, Kipling C, Lecren ED, 1958. The invetted microscope method of estimating algal number and the statistical basis of estimating by couting. Hydrobiologia 11:980-985.

McPhaden M, Zebiak SE, Glantz MH, 2006. ENSO as an integrating concept in Earth science. Science 314:1740-1745.

Magurran AE, Baillie SR, Buckland ST, Dick JMP, Elston DA, Scott EM, Smith RI, Somerfield PJ, Watt AD, 2010. Longterm datasets in biodiversity research and monitoring: assessing change in ecological communities through time. Tree 25:574-582.

Margalef R, 1983. Limnologia. Omega, Barcelona: 1010 pp.

Milzow C, Kgotlhang L, Bauer-Gottwein P, Meier P, Kinzelbach W, 2009. Regional review: the hydrology of the Okavango Delta, Botswana - processes, data and modelling. Hydrogeol. J. 17:1297-1328.

Nabout JC, Nogueira IS, Oliveira LG, Morais RR, 2007. Phytoplankton diversity (alpha, beta, and gamma) from the Araguaia River tropical floodplain lakes (central Brazil). Hydrobiologia 557:455-461.

Neiff JJ, 1990. [Ideas para la interpretacion ecologica del
Paraná].[Article in Portuguese]. Interciência 15:424-441.

Neiff JJ, 2001. Biodiversity in some tropical wetlands systems of South America, p. 119-139. In: B. Gopal, W.J. Junk and J.A. Davis (eds.), Biodiversity in wetlands: assessment, function and conservation. Backhuys Publ., Leiden.

Neiff JJ, Neiff M, 2003. [PULSO: software para análisis de fenómenos recurrentes].[in Spanish]. Available from: http://www. neiff.com.ar

Nogueira IS, Nabout JC, Ibañez MSR, Bourgoin LM, 2010. Determinants of beta diversity: the relative importance of environmental and spatial processes in structuring phytoplankton communities in an Amazonian floodplain. Acta Limnol. Brasil. 22:247-256.

Özkan K, Jeppessen E, Søndergaard M, Lauridsen TL, Liboriussen L, Svennin JC, 2013. Contrasting roles of water chemistry, lake morphology, land-use, climate and spatial processes in driving phytoplankton richness in the Danish landscape. Hydrobiologia 710:173-187.

Padial AA, Siqueira T, Heino J, Vieira LCG, Bonecker CC, Lansac-Tôha FA, Rodrigues LC, Takeda AM, Train S, Velho LFM, Bini LM, 2012. Relationships between multiple biological groups and classification schemes in a Neotropical floodplain. Ecol. Ind. 13:55-65.

Padisák J, Crossetti LO, Naselli-Flores L, 2009. Use and m issue in the application of the phytoplankton functional classification: a critical review with updates. Hydrobiologia 621:1-19.

Pinto PT, Lombardo R, O'Farrell I, Izaguire I, 2015. Drivers shaping phytoplankton diversity and composition in a humid Pampean floodplain lake (Natural Reserve). Hydrobiologia 752:77-89.

R Core Team, 2012. R: A language and environment for statistical computing. R Foundation for Statistical Computing, Vienna, Austria. Available from: http://www.R-project.org/

Reynolds CS, 1998. Functional morphology and the adaptive strategies of freshwater phytoplankton, p. 388-483. In: C.D. Sandgren (ed.), Growth and reproductive strategies of freshwater phytoplankton. Cambridge University Press, New York.

Reynolds CS, Maberly SC, Parker JE, De Ville MM, 2012. Forty years of monitoring water quality in Grasmere (English Lake District): separating the effects of enrichment by treated sewage and hydraulic flushing on phytoplankton ecology. Freshwater Biol. 57:384-399.

Reynolds CS, Huszar VLM, Kruk C, Naselli-Flores L, Melo S, 2002. Towards a functional classification of the freshwater phytoplankton. J. Plankton Res. 2:417-428.

Ricklefs RE, 1987. Community diversity: relative roles of local and regional processes. Science 235:167-171.

Roberto MC, Santana NF, Thomaz SM, 2009. Limnology in the Upper Paraná River floodplain: large-scale spatial and temporal patterns, and the influence of reservoirs. Braz. J. Biol. 69:717-725.

Rodrigues LC, Train S, Bovo-Scomparin VM, Jati S, Borsalli CCJ, Marengoni E, 2009. Interannual variability of phytoplankton in the main rivers of the Upper Paraná River floodplain, Brazil: influence of upstream reservoirs. Braz. J. Biol. 69:501-516.

Rodrigues LC, Simões NR, Bovo-Scomparin VM, Jati S, Santana NF, Roberto MC, Train S, 2015. Phytoplankton alpha diversity as an indicator of environmental changes in a neotropical floodplain. Ecol. Indic. 48:334-341. 
Simões NR, Dias JD, Leal CM, Souza LBM, Lansac-Tôha FA, Bonecker CC, 2013. Floods control the influence of environmental gradients on the diversity of zooplankton communities in a neotropical floodplain. Aquat. Sci.s 75:607-617.

Souza Filho EE, 2009. Evaluation of the Upper Paraná River discharge controlled by reservoirs. Braz. J. Biol. 69:707-716.

Souza Filho EE, Rocha PC, Comunello E, Stevaux JC, 2004. Effects of the Porto Primavera Dam on physical environment of the downstream floodplain, p. 55-74. In: S.M. Thomaz, A.A. Agostinho and N.S. Hahn (eds.), The Upper Paraná River floodplain: physical aspects, ecology and conservation. Backhuys Publ., Leiden.

Souza Filho EE, Stevaux JC, 2004. Geology and geomorphology of the Baía-Curutuba-Ivinheima River complex, p. 130. In: S.M. Thomaz, A.A. Agostinho and N.S. Hahn (eds.), The Upper Paraná River floodplain: physical aspects, ecology and conservation. Backhuys Publ., Leiden.

StatSoft, 2005. Statistica - data analysis software system - ver. 7.1. Available from: http://www.statisoft.inc

Tilman D, Downing JA, 1994. Biodiversity and stability in grasslands. Nature 367:363-365.

Thomaz SM, Pagioro TA, Bini LM, Roberto MC, Rocha RRA, 2004. Limnological characterization of the aquatic environments and the influence of water levels, p. 75-102. In: S.M. Thomaz, A.A. Agostinho and N.S. Hahn (eds.), The Upper Paraná River floodplain: physical aspects, ecology and conservation. Backhuys Publ., Leiden.
Thomaz SM, Bini LM, Bozelli R, 2007. Floods increase similarity among aquatic habitats in river-floodplain systems. Hydrobiologia 579:1-13.

Train S, Rodrigues LC, 1998. Temporal fluctuations of the phytoplankton community of the Baia River, in the upper Paraná River floodplain, Mato Grosso do Sul, Brazil. Hydrobiologia 361:125-134.

Train S, Oliveira MD, Quevedo MT, 2000. [Dinâmica sazonal da comunidade fitoplanctônica de um canal lateral (Canal Cortado) do Alto Rio Paraná (PR, Brasil)].[Article in Portuguese]. Acta Sci. Biol. Sci. 22:389-395.

Train S, Rodrigues LC, 2004. Phytoplankton assemblage, p. 103-124. In: S.M. Thomaz, A.A. Agostinho and N.S. Hahn (eds.), The Upper Paraná River floodplain: physical aspects, ecology and conservation. Backhuys Publ., Leiden.

Utermöhl H, 1958. [Zur Vervollkommnung der quantitativen Phytoplankton-Methodik]. Int.e Ver. The. 9:1-38.

Ward JV, Tockner K, 2001. Biodiversity: towards a unifying theme for river ecology. Freshwater Biol. 46:807-819.

Ward JV, Tockner K, Schiemer F, 1999. Biodiversity of floodplain river ecosystems: ecotones and connectivity. Regul. River. 15:125-139.

Weyhenmeyer GA, Peter H, Willén E, 2013. Shifts in phytoplankton species richness and biomass along a latitudinal gradient - consequences for relationships between biodiversity and ecosystem functioning. Freshwater Biol. 58:612-623. 